Images in...

\title{
A young man with slowly progressive ataxia
}

\author{
Seema Mahant, ${ }^{1}$ Piyudeo Mahant, ${ }^{2}$ Rakesh Biswas ${ }^{3}$ \\ 1Department of General Medicine, PCMS \& RC, Bhopal, India; \\ 2Department of Radiodiagnosis, PCMS \& RC, Bhopal, India; \\ ${ }^{3}$ Department of Medicine, People's College of Medical Sciences, Bhopal, India \\ Correspondence to Professor Rakesh Biswas, rakesh7biswas@gmail.com
}

\section{DESCRIPTION}

A 22-year-old man presented with 5 years history of progressive neurological symptoms manifesting as ataxia, dysarthria and vertigo. The patient was apparently normal 5 years back when he had an episode of fever for 4-5 days that got relieved spontaneously and after few days the patient noticed swaying from side to side during work and his gait become ataxic. It was progressive with time and at present the patient is unable to walk without support. After 1 month of ataxia, the patient started having a slurred speech. For the last 3 months the patient was having mild vertigo without any associated vomiting. There

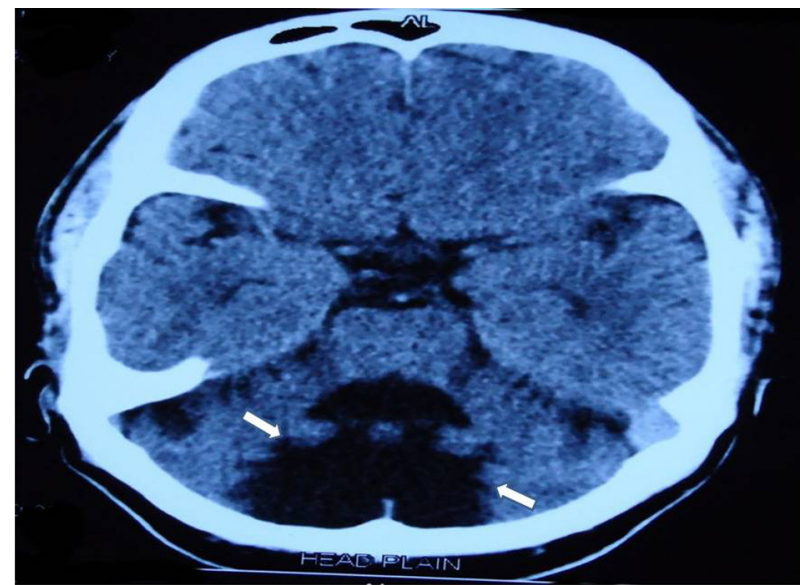

Figure 1 CT head of the patient.

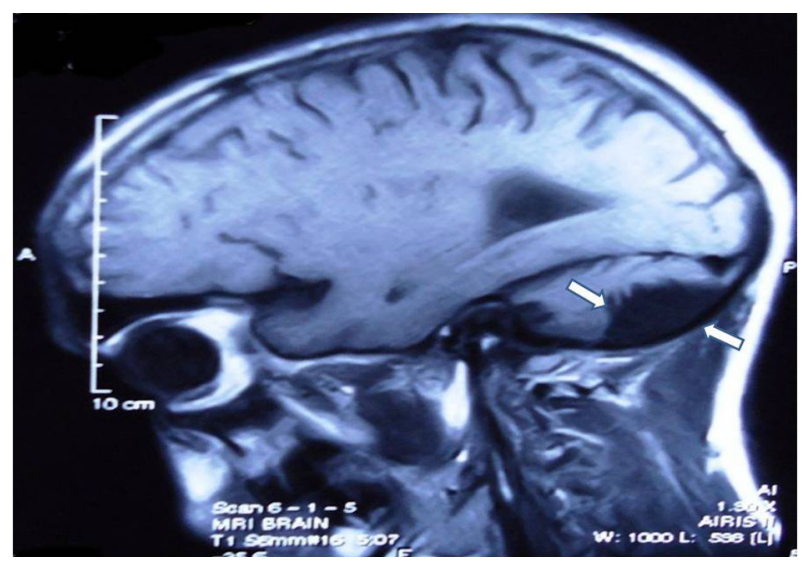

Figure 2 Cranial MRI of the patient. was no history of altered sensorium, motor weakness or sensory loss. There was no history of seizures, fever and headache or head injury. On neurological examination, the patient was alert, friendly, cooperative and oriented to time, place and person. His speech appeared to scan each syllable. The patient had horizontal nystagmus on both vertical and lateral gaze. There was bilateral finger-to-nose ataxia and impaired heel knee test. The motor strength and reflexes were normal. He was investigated with a CT head (figure 1) and MRI (figures 2 and 3).

The CT scan of the head in this patient revealed a large cyst in the posterior fossa (figure 1). On MRI (figures 2 and 3), T1 weighted sagittal image of the brain showed a large cerebrospinal-fluid filled cyst in the posterior fossa and a large cystic lesion occupying nearly the entire posterior fossa that was incorporating and appeared inseparable from the fourth ventricle (figure 2). Dysplasia of the cerebellar cortices was also noted (figure 3 ). These changes were consistent with the Dandy-Walker malformation.

The Dandy-Walker complex is a rare congenital malformation and is morphologically characterised by agenesis or hypoplasia of the cerebellar vermis, cystic dilatation of the fourth ventricle and enlargement of the posterior fossa. It is a genetically sporadic disorder that occurs one in every 25000 live births, mostly in females. ${ }^{1}$ Clinical manifestation in adults is totally different from neonatal presentation. In adults, the most common symptoms are headaches, papilloedema and vomiting resulting from increased intracranial pressure. Some adults may be asymptomatic with normal intracranial pressure or they may have only mild

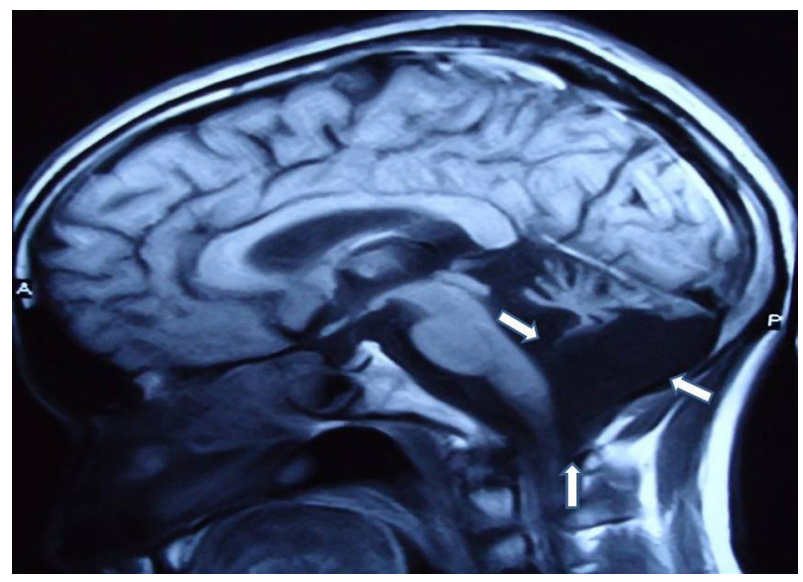

Figure 3 Cranial MRI of the patient. 


\section{BMJ Case Reports}

unsteadiness of gait or intellectual impairment until the syndrome is activated by head trauma or a systemic infection. ${ }^{2}$ Our patient developed the symptoms at the age of 17 years after a febrile illness. Most patients with the adult Dandy-Walker syndrome are referred for lateral ventriculoperitoneal or cysto-peritoneal shunting procedures. ${ }^{4}$

\section{Learning points}

- Adult slow progressive ataxia can be due to congenital malformation of cerebellum.

- Dandy Walker syndrome can manifest late in adults sometimes precipitated by infection or trauma.
Competing interests None.

Patient consent Obtained.

\section{REFERENCES}

1. National Institute of Neurological Disorders and Stroke, 'NINDS Dandy-Walker Syndrome Information Page,' http://www.ninds.nih.gov/disorders/dandywalker/ dandywalker.htm. Last updated September 16, 2008 (accessed 6 July 2009).

2. Brown JR. The Dandy-Walker Syndrome. Handbook of Clinical Neurology. New York: American Elsevier Publishing Co 1977:623-46.

3. Hirsch JF, Pierre-Kahn A, Renier D, et al. The Dandy-Walker malformation. A review of 40 cases. J Neurosurg 1984;61:515-22.

4. Naidich TP, Radkowski MA, McLone DG, et al. Chronic cerebral herniation in shunted Dandy-Walker malformation. Radiology 1986;158:431-4.

This pdf has been created automatically from the final edited text and images.

Copyright 2012 BMJ Publishing Group. All rights reserved. For permission to reuse any of this content visit

http://group.bmj.com/group/rights-licensing/permissions.

BMJ Case Report Fellows may re-use this article for personal use and teaching without any further permission.

Please cite this article as follows (you will need to access the article online to obtain the date of publication).

Mahant S, Mahant P, Biswas R. A young man with slowly progressive ataxia. BMJ Case Reports 2012;10.1136/bcr.01.2012.5686, Published XXX

Become a Fellow of BMJ Case Reports today and you can:

- Submit as many cases as you like

- Enjoy fast sympathetic peer review and rapid publication of accepted articles

- Access all the published articles

- Re-use any of the published material for personal use and teaching without further permission

For information on Institutional Fellowships contact consortiasales@bmjgroup.com

Visit casereports.bmj.com for more articles like this and to become a Fellow

Keep up to date with all published cases by signing up for an alert (all we need is your email address) http://casereports.bmj.com/cgi/alerts/etoc 